\title{
Association of insulin resistance and GLP-2 secretion in obesity: a pilot study
}

\author{
Associação entre resistência insulínica e secreção \\ de GLP-2 em obesos: um estudo piloto
}

Bruno Geloneze', Marcelo Miranda de Oliveira Lima', José Carlos Pareja', Maria Rita Lazzarini Barreto', Daniéla Oliveira Magro'

\footnotetext{
' Laboratório de Investigação em Metabolismo e Diabetes (LIMED) do Gastrocentro, Faculdade de Ciências Médicas, Universidade Estadual de Campinas (Unicamp), Campinas, SP, Brazil

Statement of authorship: Bruno Geloneze: design, data analysis and interpretation, contribution to discussion. Marcelo Miranda de Oliveira Lima: contribution to discussion. José Carlos Pareja: contribution to discussion. Maria Rita Lazzarini Barreto: data collection.

Daniéla Oliveira Magro: design, data analysis and interpretation, contribution to discussion, revision/edition of manuscript.
}

Correspondence to: Daniéla Oliveira Magro LIMED, Gastrocentro, Unicamp

Rua Carlos Chagas, 420 13081-970 - Campinas, SP, Brazil danimagro@terra.com.b

Received on Oct/29/2012 Accepted on Aug/1/2013

\begin{abstract}
Objective: The objective of this pilot study was to determine whether glugagon-like peptide 2 (GLP2) secretion relates to insulin sensitivity (IS) in obese subjects. Subjects and methods: Twenty four obese subjects [body mass index (BMI) $40.0 \pm 3.0 \mathrm{~kg} / \mathrm{m}^{2}$ (mean \pm standard deviation)] were included, nine of which were male, age $43 \pm 8$ years. Twelve subjects had type 2 diabetes, all treated with oral anti-diabetic agents only. The subjects were submitted to standard meal tolerance test (MTT) for dosage of the curves: glucose, insulin, and GLP-2. Insulin sensitivity was measured by HOMA-IR, and OGIS was derived from the MTT. Spearman linear correlations and partial correlations were obtained. Results: There was an inverse relationship between the GLP-2 secretion and IS: HOMA-IR correlated with GLP-2 AUC ( $R=0.504 ; p=0.012)$, and OGIS correlated with GLP-2 incremental AUC $(R=-0.54$; $p=0.054)$. The correlation persisted after controlling for BMI. Conclusion: We found an association of GLP-2 secretion and insulin resistance (IR). The understanding of the underlying mechanisms may provide future directions in the pharmacological manipulation of incretins, and in the treatment of obesity and related metabolic disorders. Arq Bras Endocrinol Metab. 2013;57(8):632-5
\end{abstract}

\section{Keywords}

GLP-2; insulin resistance; HOMA-IR; OGIS; obese patients

\section{RESUMO}

Objetivo: O objetivo deste estudo piloto foi determinar a relação entre a secreção de glugagon like peptide 2 (GLP-2) e a sensibilidade insulínica (SI) em indivíduos obesos. Sujeitos e métodos: Vinte e quatro indivíduos obesos [IMC $40.0 \pm 3.0 \mathrm{~kg} / \mathrm{m}^{2}$ (média \pm desvio-padrão)] foram incluídos no estudo, sendo 9 homens, com idade de $43 \pm 8$ anos. Do total, 12 indivíduos tinham diabetes tipo 2 , todos tratados somente com antidiabéticos orais. Os sujeitos foram submetidos ao teste de refeição padrão (MTT) para dosagens das curvas: glicose, insulina e GLP-2. A sensibilidade insulínica foi mensurada pelos HOMA-IR e OGIS, obtidos pelos valores do MTT. As correlações lineares e correlações parciais foram obtidas. Resultados: Observou-se uma relação inversa entre a secreção de GLP-2 e SI: HOMA-IR correlacionou-se com GLP-2 AUC $(R=0,504 ; p=0,012)$ e OGIS correlacionou-se com GLP-2 incremental AUC $(R=-0,54 ; p=0,054)$. A correlação persistiu controlando o IMC. Conclusão: Encontramos uma associação entre a secreção de GLP-2 e a resistência insulínica. A compreensão desses mecanismos poderá direcionar o futuro farmacológico da manipulação de incretinas no tratamento da obesidade e das desordens metabólicas. Arq Bras Endocrinol Metab. 2013;57(8):632-5

\section{Descritores}

GLP-2; resistência insulínica; HOMA-IR; OGIS; obesos

\section{INTRODUCTION}

G lucagon-like peptide-2 (GLP-2) is a hormone co-secreted with glucagon-like peptide- 1 from enteroendocrine cells in the small and large bowels, also expressed in the pancreas and the brain $(1,2)$. GLP-2 secretion is regulated by food nutrients, mainly fat and carbohydrates, and targets receptors in the gastrointestinal tract, from the stomach to the colon. The major known action of GLP-2 is mucosal growth, especially in the proximal bowel, increasing villous height and crypt cell proliferation, and inhibiting apoptosis in both the crypt and villous compartments (3). 
The potent intestinotrophic action of GLP-2 results in increased nutrient absorption, which justifies interest in potential therapeutic applications in conditions of malabsorption and intestinal injury/atrophy, with promising initial results $(4,5)$. On the other hand, little is known about the role of this hormone in conditions related to increased uptake of energy and macronutrients, specially fatty acids, such as obesity and insulin resistance (IR).

Our hypothesis is that insulin sensitivity is influenced by increased absorption of nutrients mediated by GLP-2. The objective of this pilot study was to determine whether GLP-2 secretion relates to insulin sensitivity (IS) in obese subjects.

\section{SUBJECTS AND METHODS}

The study was approved by the Institutional Ethics Review Board at University of Campinas (Unicamp number: 801/2008). All participants provided written informed consent before participation. Twenty four obese subjects [body mass index (BMI) $40.0 \pm 3.0 \mathrm{~kg} / \mathrm{m}^{2}$ (mean \pm standard deviation)] were included, nine of which were male, aged $43 \pm 8$ years. Twelve subjects had type 2 diabetes, all treated with metformin and/or sulfonylureas only.

After an overnight fast (12 h), subjects were submitted to standard meal tolerance test (MTT), based in a mixed meal containing $515 \mathrm{kcal}(41.8 \%$ fat, $40.7 \%$ carbohydrates, and $17.5 \%$ protein). For diabetic subjects, oral antidiabetic drugs were discontinued one day before the test. Blood samples were drawn for glucose, insulin, and GLP-2 at -15, 0, 30, 45, 60, 90, 120, 150, and 180 minutes. Glucose was determined by the glucose oxidase method. For GLP-2 analysis, blood samples were collected in tubes with EDTA3 plus Sigma diprotin. Serum samples were stored in a freezer at $-80^{\circ} \mathrm{C}$ for posterior analysis of insulin (ELISA, Bayer Corp.) and GLP-2 (ELISA, Millipore Corp.).

\section{Statistical methods}

The area under the curve (AUC) of GLP-2, glucose and insulin were calculated by the trapezoidal method. The incremental AUC was calculated as total AUC minus the area under the basal value.

Insulin sensitivity (IS) was estimated by two methods: (1) the Homeostatic Model Assessment (HOMA-IR) from the formula [glucose $(\mathrm{mmol} / \mathrm{L}) \mathrm{X}$ Insulin $(\mu \mathrm{U} /$ $\mathrm{mL}) / 22.5$ ], for which higher values represent lower IS; and (2) the Oral Glucose Insulin Sensitivity (OGIS) obtained from MTT, which represents the postprandial glucose clearance adjusted for body surface $\operatorname{area}^{5}$, and for which higher values represent higher IS.

SSPS 16.0 was used for statistical analyses with Spearman linear correlations and partial correlations. Statistical significance was assumed if $\mathrm{p}<0.05$.

\section{RESULTS}

The metabolic characteristics of the subjects are presented in table 1 .

Table 1. Metabolic characteristics of the studied subjects

\begin{tabular}{|c|c|}
\hline Characteristic & Mean \pm SD \\
\hline Fasting plasma glucose $(\mathrm{mg} / \mathrm{dL})^{\star \star}$ & $155.5 \pm 45.2$ \\
\hline Fasting plasma insulin $(\mu \mathrm{g} / \mathrm{dL})^{\star \star}$ & $19.5 \pm 12.2$ \\
\hline HOMA-IR* & $6.2 \pm 5.5$ \\
\hline AUC GLP-2 (ng/mL x min) ${ }^{\star \star}$ & $1062.16 \pm 204.12$ \\
\hline AUCi GLP-2 (ng/mL x min) ${ }^{\star *}$ & $183.2 \pm 164$ \\
\hline OGIS ${ }^{\star *}$ & $300.5 \pm 18.75$ \\
\hline
\end{tabular}

HOMA-IR: homeostatic model assessment/insulin resistance; AUC GLP-2: area under the curve of glucagon-like peptide 2; AUCi GLP-2: incremental area under the curve of glucagon-like peptide 2; OGIS: oral glucose insulin sensitivity.

${ }^{* *}$ Mean \pm standard deviation.

Insulin sensitivity (IS) and GLP-2 AUCs were statistically similar between diabetic and non-diabetic subjects (data not shown).

We observed an inverse relationship between the GLP-2 secretion and IS: HOMA-IR correlated with GLP-2 AUC $(\mathrm{R}=0.504 ; \mathrm{p}=0.012)$ (Figure 1$)$, and OGIS correlated with GLP-2 incremental AUC $(\mathrm{R}=$ $-0.54 ; \mathrm{p}=0.054)$ (Figure 2$)$. The correlation persisted after controlling for BMI.

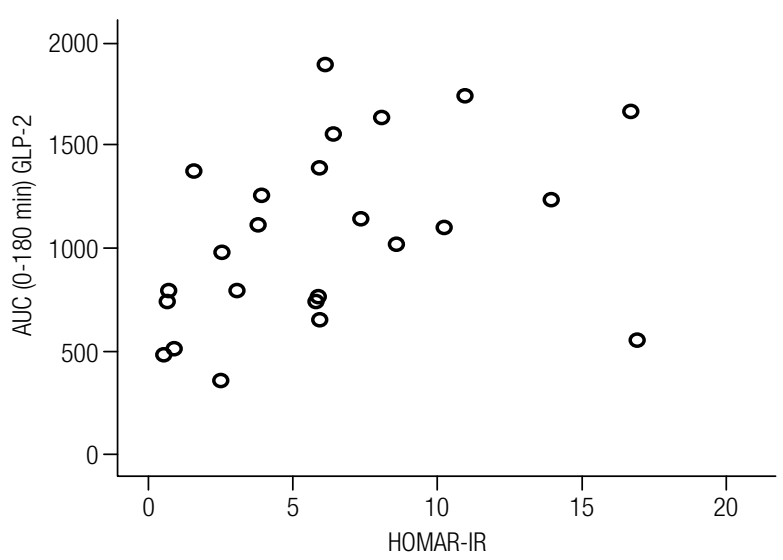

Figure 1. Relationship between GLP-2 area under the curve (AUC) $(\mathrm{ng} / \mathrm{mL}$ $x$ min) and insulin resistance index (HOMA-IR). 


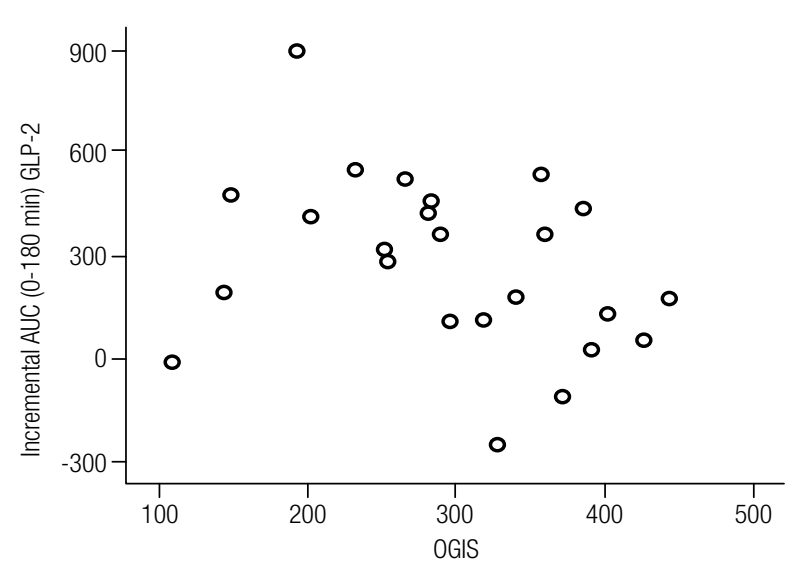

Figure 2. Relationship between GLP-2 incremental area under the curve (AUC) (ng/mL x min) and insulin sensitivity index (OGIS).

\section{DISCUSSION}

We report, for the first time, an association between GLP-2 secretion and IR in obese subjects.

The strength of our finding is the use of two complementary indexes of IS: one based in a fasting basal method (HOMA-IR), which measures mainly hepatic IS (6); and one that is a postprandial, dynamic method (OGIS) that measures whole-body IS (hepatic and peripheral) (5).

There are some hypotheses to explain this finding. The first hypothesis is that GLP-2 induced an increased absorption of nutrients, especially fatty acids, which could contribute to IR. GLP-2 has an intestinotrophic effect in the proximal and distal bowels (7), and has acute effects in intestinal fat absorption and lipoprotein production, which result in increased postprandial circulating triglycerides and free fatty acids in rodents (8) and humans (9). Fatty acids are a key factor for IR in skeletal muscles and liver by a number of mechanisms: preferential oxidation over glucose; impaired insulin signaling and glucose transport; inflammation and oxidative stress secondary either to fat metabolites (ceramides, diacylglycerol, acyl-CoA) or binding to fatty acid receptors (G-coupled protein or peroxisome proliferator-activated receptors) (10).

The intestinal microbiota could have a contribution to this hypothesis. Food fermentation both increases energy harvesting in animal and human obesity (11) and produces short-chain fatty acids linked to increased expression of pro-enteroglucagon in rodents (12) and to proximal and distal bowel hypertrophy (13).

There are some counterpoints to the discussion above. First, we cannot exclude the hypothesis that increased GLP-2 secretion could be a manifestation of intestinal IR (14). Second, Cani and cols. (15) demonstrated that GLP-2 has a protective effect on metabolic endotoxemia in mice, demonstrated by lower plasma lipopolysaccharide (LPS) and cytokines and decreased lipid content and inflammation in the liver. Such effect was, at least in part, related to lower intestinal permeability, preventing LPS translocation.

A second hypothesis is that glucagon could be the link between GLP-2 and IR. GLP-2 directly stimulates glucagon secretion and counteracts the glucagonostatic action of GLP-1 in healthy subjects (9), and in type 1 and type 2 diabetic subjects $(3,16)$. Glucagon is counter-regulatory to insulin action, increasing glucose output and inhibiting glucose uptake in the liver, and has been linked to IR in obese subjects with normal or impaired glucose tolerance $(17,18)$.

Some limitations of the study are that we have not assayed fatty acids and glucagon, and have not evaluated intestinal absorption and histology.

The relationship of GLP-2 and IR should be considered in future studies of pharmacological use of GLP-2 and its analogues, especially for potential adverse metabolic events.

We found an association of GLP-2 secretion and IR. The understanding of the underlying mechanisms may provide future directions in the pharmacological manipulation of incretins, and in the treatment of obesity and related metabolic disorders.

Acknowledgements: grants for this study were provided by Fundação de Apoio à Pesquisa do Estado de São Paulo (Fapesp), São Paulo, Brazil (Protocol - 2009/50430-6).

Disclosure: no potential conflict of interest relevant to this article was reported.

\section{REFERENCES}

1. Drucker DJ. Glucagon like peptide 2. J Clin Endocrinol Metab. 2001;86:1759-64.

2. Lovshin J, Drucker DJ. Synthesis, secretion and biological actions of the glucagon-like peptides. Pediatr Diabetes. 2000;1:49-57.

3. Lund A, Vilsboll T, Bagger JI, Holst JJ, Knop FK. The separate and combined impact of the intestinal secretion in type 2 diabetes hormones, GIP, GLP-1, and GLP-2, on glucagon. Am J Physiol Endocrinol Metab. 2011;300:E1038-46.

4. Jeppesen PB. Glucagon-like peptide-2: update of the recent clinical trials. Gastroenterology. 2006;130(2):S127-31.

5. Mari A, Murphy E, Ludvik N, Nolan JJ. A model-based method for assessing insulin sensitivity from the oral glucose tolerance test. Diabetes Care. 2001;24(3):539-48.

6. Geloneze B, Vasques AC, Stabe CFC, Pareja JC, Rosado LE, Queiroz EC, et al. HOMA1-IR and HOMA2-IR indexes in identifying 
insulin resistance and metabolic syndrome: Brazilian Metabolic Syndrome Study (BRAMS). Arq Bras Endocrinol Metabol. 2009;53(2):281-87.

7. Drucker DJ, Erlich P, Asa SL, Brubaker PL. Induction of intestinal epithelial proliferation by glucagon-like peptide 2. Proc Natl Acad Sci U S A. 1996;93:7911-16.

8. Hsieh J, Longuet $\mathrm{C}$, Maida $\mathrm{A}$, Bahrami J, Xu E, Baker $\mathrm{CL}$, et al. Glucagon-like peptide-2 increases intestinal lipid absorption and chylomicron production via CD36. Gastroenterology. 2009;137:997-1005.

9. Meier JJ, Nauck MA, Pott A, Heinze K, Goetze O, Bulut K, et al. Glucagon-like peptide 2 stimulates glucagon secretion, enhances lipid absorption, and inhibits gastric acid secretion in humans. Gastroenterology. 2006;130:44-54.

10. Delarue J, Magnan C. Free fatty acids and insulin resistance. Curr Opin Clin Nutr Metab Care. 2007;10(2):142-8.

11. Turnbaugh PJ, Ley RE, Mahowald MA, Magrini V, Mardis ER, Gordon Jl. An obesity-associated gut microbiome with increased capacity for energy harvest. Nature. 2006;444(7122):1027-31.
12. Roberge JN, Brubaker PL. Secretion of proglucagon-derived peptides in response to intestinal luminal nutrients. Endocrinology. 1991;128(6):3169-74.

13. Cummings JH. Short chain fatty acids in the human colon. Gut. 1981;22(9):763-79.

14. Adeli K, Lewis GF. Intestinal lipoprotein overproduction in insulinresistant states. Curr Opin Lipidol. 2008;19(3):221-8.

15. Cani PD, Possemiers S, Van de Wiele T, GuiotY, Everard A, Rottier $O$, et al. Changes in gut microbiota control inflammation in obese mice through a mechanism involving GLP-2-driven improvement of gut permeability. Gut. 2009;58(8):1091-103.

16. Christensen M, Knop FK, Vilsboll T, Aaboe K, Holst JJ, Madsbad $S$, et al. Glucagon-like peptide-2, but not glucose-dependent insulinotropic polypeptide, stimulates glucagon release in patients with type 1 diabetes. Regul Pept. 2010;163(1-3):96-101.

17. Ahrén B. Glucagon secretion in relation to insulin sensitivity in healthy subjects. Diabetologia. 2006;49(1):117-22.

18. Weiss R, D'Adamo E, Santoro N, Hershkop K, Caprio S. Basal alpha-cell up-regulation in obese insulin-resistant adolescents. $J$ Clin Endocrinol Metab. 2011;96(1):91-7. 